\title{
Exploring Double Skin Façade as Strategy For Achieving Thermal Comfort in Proposed Mixed Use Office Complex Kano, Nigeria
}

\author{
${ }^{1} \mathrm{H}$. Bello, ${ }^{1}$ B. Hamza and ${ }^{2 *}$ F. Abdulhamid \\ ${ }^{1}$ Department of Architecture, \\ Ahmadu Bello University Zaria \\ ${ }^{2}$ Modibbo Adama University, \\ Yola
}

Email: abdulhamidfahad@gmail.com

\begin{abstract}
Thermal comfort can be defined as a state of mind which a human feels neither too hot nor too cold. Thermal discomfort in the case of hot humid climates, becomes a great threat to our livelihood and thermal comfort in offices in general. The ability of designers to harness and use the building envelope make life much better and livable is of great importance. This research seeks to use Double skin façade as a strategy for improving indoor thermal comfort by testing the air gap between the double skins. Climate and Weather readings were obtained and used to simulate and check the effect of Double skin façade in improving indoor thermal comfort in office complex. Double skin facade has been suggested by many researchers as a possible alternative technique for improving indoor thermal comfort. The double skin facade study in this research involved computer simulation using Emissions Control Optimization TEChnology (ECOTEC). The result of the final base case model shows that double skin façade can increase the indoor thermal comfort in a building and the wider the air gap, the higher the thermal comfort by showing the hours of comfort and discomfort to the simulated office building. The other important factor is that it can continuously induce the flow of natural ventilation, regardless of the available wind outside of the office complex building. This effect is significant toward improving the thermal comfort performance in the office complex through passive natural ventilation.
\end{abstract}

Keywords: Thermal comfort, Computer simulation, Double skin façade, natural ventilation.

\section{INTRODUCTION}

It is very important for architects and engineers to put into consideration comfort, health and well-being of the occupants while designing buildings. American Society for Heating, Refrigerating and Air Conditioning Engineers (ASHRAE), defined thermal comfort as "the condition of the mind in which satisfaction is expressed with the thermal environment". Thus positive comfort conditions are those that do not distract by causing unpleasant sensations of temperature and humidity while in negative terms, it's a state in which we are not conscious of being too hot or too cold (Garba, 2015). 
The definition of thermal comfort leaves open as to what is meant by condition of the mind or satisfaction, but it correctly emphasizes that the judgment of comfort is a cognitive process involving many inputs influenced by physical, physiological, psychological, and other factors. Khadijah 2016, opined that temperature, humidity and wind speed are the challenge-able variables of thermal comfort in a given area.

Comfort index simply means that during those hours which fall under comfortable class, temperature, humidity and wind speed conditions are optimum for people to carry out light tomoderate physical activities without the constraints of weather (Mohan et al, 2014). In other words, under the temperature conditions requisite for "comfortable" office, one feels naturally comfortable without the aid of any anthropogenic support system (Mohan et al, 2014).

Studies have shown that employee satisfaction with the thermal comfort of their workplace plays a significant role in both employee retention and productivity. One study even revealed that employees consider workplace comfort second only to compensation in terms of benefits (American Society of Interior Designers, 2016).

According to Building Owners and Managers Association (BOMA, 2017) building class definitions categorize office buildings as Class $\mathrm{A}$, which are the most prestigious office complex in the best locations (BOMA, 2017). Class B are slightly older buildings with good management and quality tenants. Class $\mathrm{B}$ office buildings commonly have an acceptable curtain wall finish, adequate mechanical, electrical and safety and security systems, and a mid-quality level of interior finish. Class $C$ have less desirable architecture, limited infrastructure and antiquated technology define these buildings. These buildings attract tenants who sign short-term leases for functional space below average rental rates (BOMA, 2017).

A double-skin facade (DSF) is a building typology consisting of two skins (a glazed outer layer and either a glazed or mixed inner layer) placed in such a way that air flows in the intermediate cavity (Poirazis, 2014). The cavity air ventilation (either natural or mechanical) is used for evacuating the radiated heat absorbed by the façade elements. The outer glazed skin can be single or double glazing units with a distance from $20 \mathrm{~cm}$ up to $2 \mathrm{~m}$ from the inner skin. Sometimes, for radiation protection, solar shading devices are placed inside the cavity.

The most common way of categorization is according to the type (geometry) of the cavity, the partitioning type, the multi-storey type, corridor façade, box-window type and shaft box type. Ali baba, (2011) put that partitioning type are composed of two transparent surfaces which are partitioned by a cavity and need for cooling during summer or heating during winter can be decreased by utilizing additional skin.

\section{METHODOLOGY}

\section{Research design}

This study adopts an experimental approach as means to finding answers to its research aim and objectives.

\section{Dependent and independent variables}

The dependent variable is thermal comfort, thermal comfort is measured in terms of indoor dry bulb air temperature, indoor relative humidity, solar radiation, and air velocity Nicol, Hunphreys, \& Roaf, (2012). The independent variables that will be studied are double skin 
façade variables. Double skin façade variables are ventilation mode, partition type and ventilation of the cavity mode. These variables will be studied as part of the process of creating a suitable base case model on which to test the performance of dependent variables which are: radiation, air temperature, relative humidity, and air velocity. The weather data (Kano weather information/data) used in the simulation are obtained from the Nigeria meteorological agency at www.nimet.gov.ng

\section{Development of the base case model.}

Plate 1 shows the base case which is a $3.6 \mathrm{~m}$ by $4.5 \mathrm{~m}$ office space of 10 floors including the ground floor with a height of $3 \mathrm{~m}$ between the floor and ceiling, $150 \mathrm{~mm}$ monolithic concrete floors and a decked roof. The double skin wall (DSF) is applied in this study to help improve indoor thermal comfort of the building interior. The external double glass walling materials are alternated for each case and all other parameters are kept constant. The total hours of discomfort are predicted from the simulations.

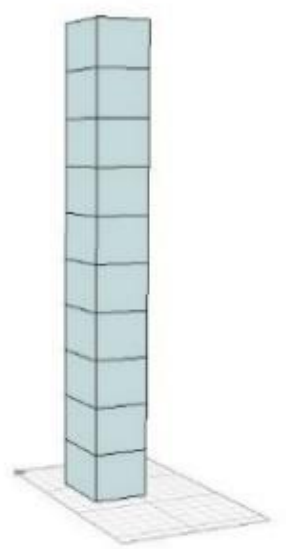

\section{Walling setup}

The double skin wall is made of $6 \mathrm{~mm}$ standard glass on both faces of a fabricated steel and aluminium frame with a $75 \mathrm{~mm}$ air gap, $150 \mathrm{~mm}$ air gap and $225 \mathrm{~mm}$ air gap. The total widths are $87 \mathrm{~mm}, 162 \mathrm{~mm}$ and $237 \mathrm{~mm}$. The thermal properties of these walling setups will be calculated using the simulation software, Ecotect and the results will be used in subsequent simulation to find the comfort levels in the interior.

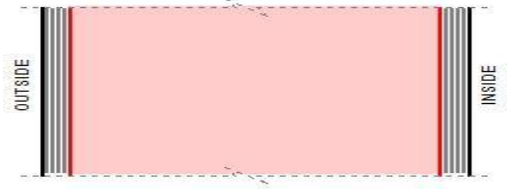

75 mm air gap

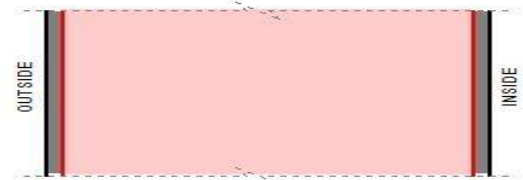

150 mm air gap

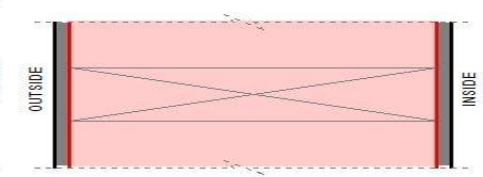

225 mm air gap

Figure 1: showing the different walling set up

\section{RESULTS}




\section{Thermal properties,}

Table 1 shows the thermal properties calculated for $75 \mathrm{~mm}$ air gap setup, $150 \mathrm{~mm}$ air gap setup and the $225 \mathrm{~mm}$ air gap setup. The table shows that the $225 \mathrm{~mm}$ air gap set up has the best thermal property as a result of its low $\mathrm{u}$-value and admittance and solar absorption.

Table 1 Thermal properties of the walls used

\begin{tabular}{llll}
\hline & 75mm Air gap & $150 \mathrm{~mm}$ Air gap & 225mm Air gap \\
\hline $\begin{array}{l}\text { U-value } \\
\text { (w/m2.K) }\end{array}$ & 2.710 & 1.720 & 1.200 \\
Thermal Admittance (w/m2.K) & 0.840 & & \\
Solar Absorption (0-1) & 0.251 & 0.880 & 0.960 \\
Visible transmittance (0-1) & 0 & 0.237 & 0.195 \\
Thermal Decrement (0-1) & 0.06 & 0 & 0 \\
Thermal Lag (hrs) & 0.42 & 0.21 & 0.47 \\
Emissivity & 0.9 & 0.75 & 1.16 \\
\hline
\end{tabular}

\section{Base case model $75 \mathrm{~mm}$ air gap}

Figures $2 \mathrm{a}, 2 \mathrm{~b}, 2 \mathrm{c}$ and $2 \mathrm{~d}$ shows the results from the simulation using the $75 \mathrm{~mm}$ air gap walls with 754 discomfort hours, 736 discomfort hours, 722 discomfort hours, 630 discomfort hours out of 3244 operational hours in a year respectively. The month of May tends to have the highest discomfort hours while there is relatively no discomfort in January, February, August, September, November and December, as months have a relatively low average temperature and thus the predicted temperature will fall within the comfort bands.

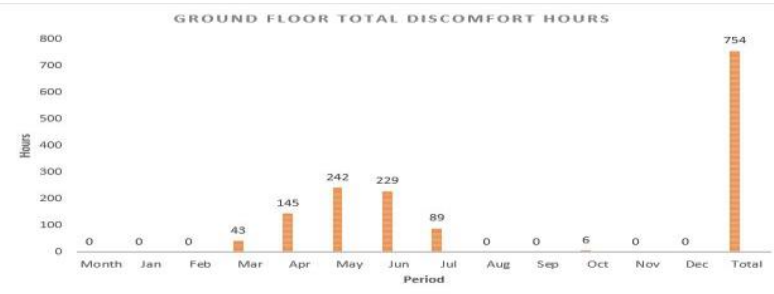

Figure 2a: Ground floor

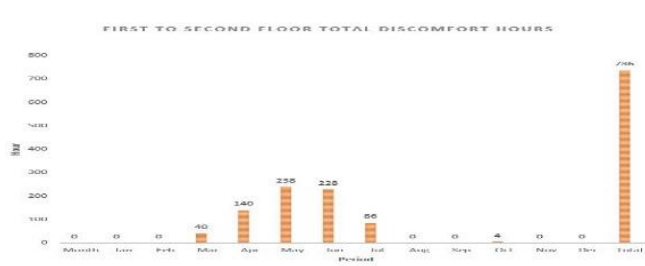

Figure 2b: First floor and Second floor

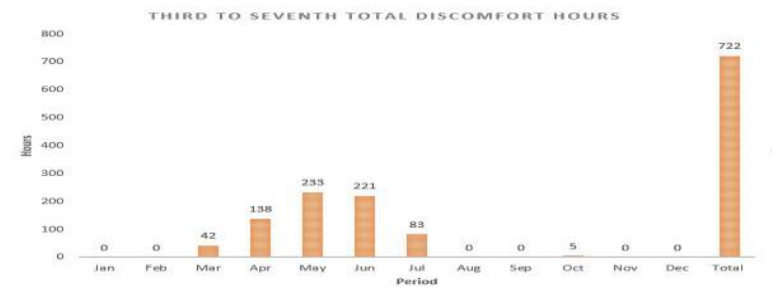

Figure 2c: Third floor to Seventh floor

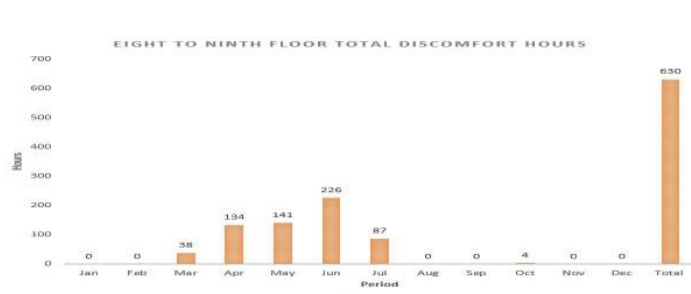

Figure 2d: Eight floor to Ninth floor

The results from simulation predicts that temperature increases are negligible at heights above 10 meters above ground level as the air temperature at this height remains almost the same. Also the results from simulation predicts that air temperature increases more rapidly at heights above 24 meters above the ground level and thus increasing the hours in which the temperature falls outside the comfort bands.

\section{$150 \mathrm{~mm}$ air gap walls}


The results from the simulation shows 730 discomfort for the ground floor in figure $3 \mathrm{a}, 613$ hours of discomfort for the first floor and second floor in figure $3 b$ while figure $3 c$ and $3 d$ shows 591 and 565 hours of discomfort respectively out of the 3244 operational hours in a year. The highest number of discomfort hours is predicted to be in May and no discomfort in January, February, August, September, November and December.

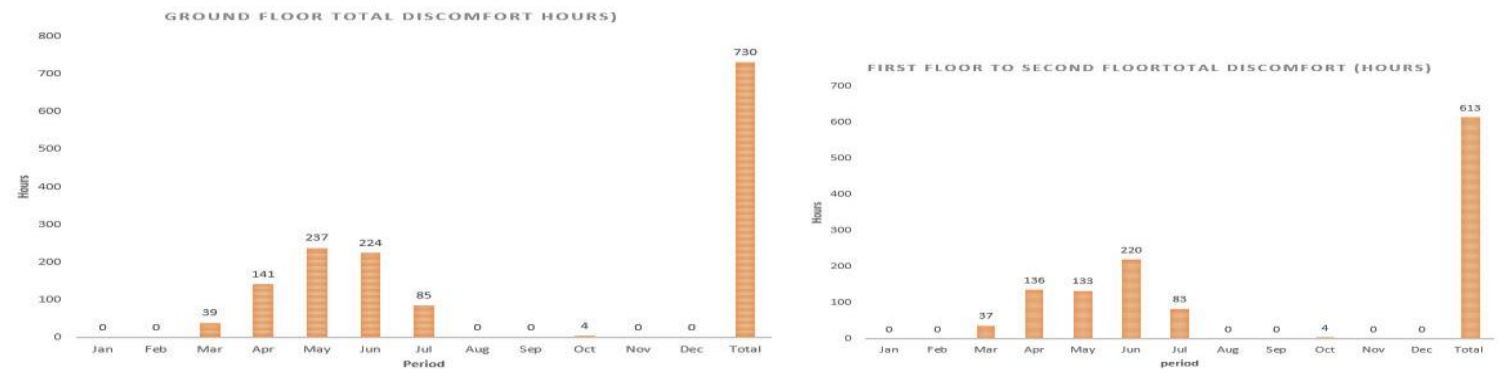

Figure 3a: Ground floor

Figure 3b: First floor to Second floor

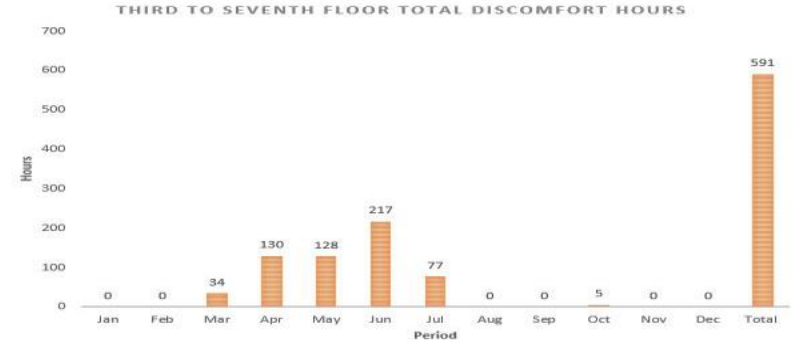

Figure 3c: Third floor to Seventh floor

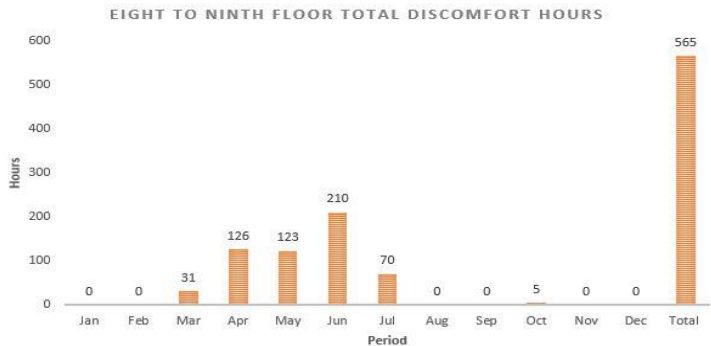

Figure 3d: Eight floor to Ninth floor

The results from simulation predicts that temperature increases are negligible at heights above 10 meters above ground level as the air temperature at this height remains almost the same from the third to the seventh floor. Also, it shows that air temperature increases more rapidly at heights above 24 meters above the ground level and thus increasing the hours in which the temperature falls outside the comfort bands.

\section{5mm air gap wall}

A total of discomfort hours of 603 was recorded after the simulation for the ground floor, 556 hours for the first and second floors, 550 hours for third to seventh floors and 540 hours for the eighth and ninth floors respectively. The highest number of discomfort hours is predicted to be in May and no discomfort in January, February, August, September, November and December. It is predicted that there will be no discomfort in these months as the months have low average temperature and thus the predicted temperature will fall within the comfort bands. 


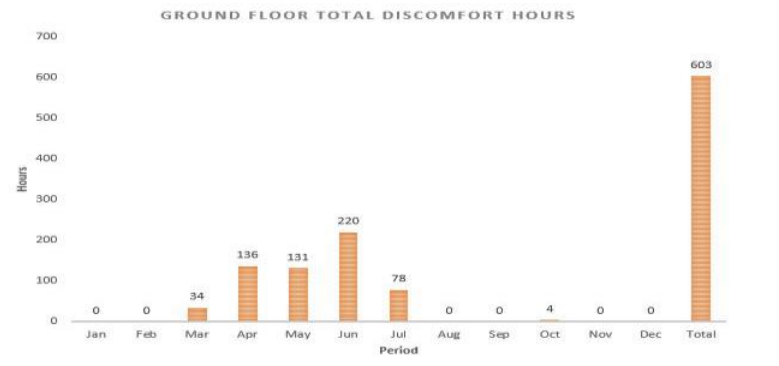

Figure 5a: Ground floor

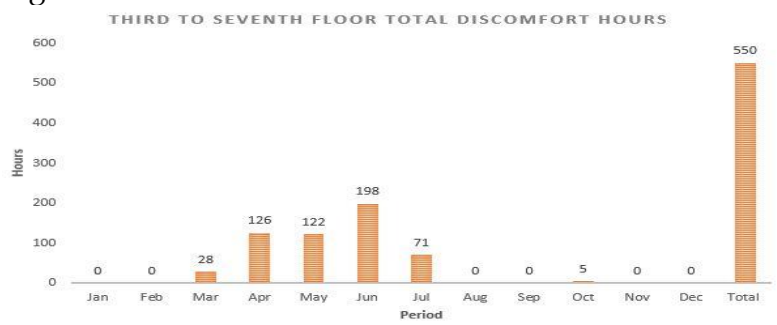

Figure 5c: Third floor to Seventh floor

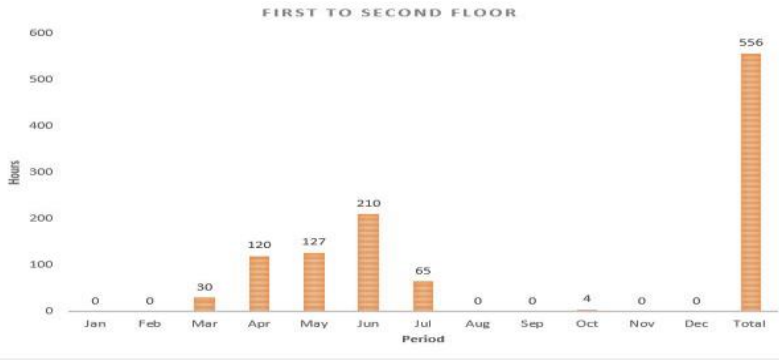

Figure 5b: First floor to Second floor

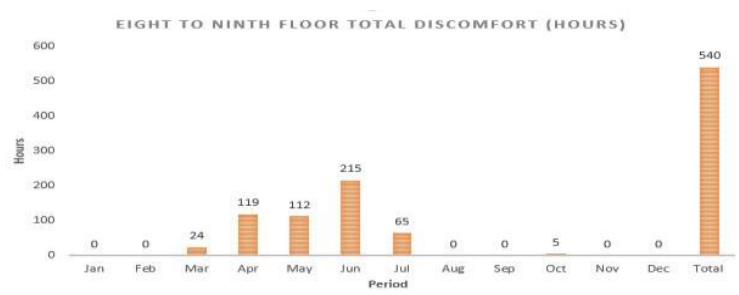

Figure 5d: Eight floor to Ninth floor

The results from simulation predicts that temperature increases are negligible at heights above 10 meters above ground level as the air temperature at this height remains almost the same, also air temperature increases more rapidly at heights above 24 meters above the ground level and thus increasing the hours in which the temperature falls outside the comfort bands.

Based on the simulation result present above, it shows that the $225 \mathrm{~mm}$ air gap wall enhances thermal comfort more than $150 \mathrm{~mm}$ air gap wall and $150 \mathrm{~mm}$ air gap wall performs better than the $75 \mathrm{~mm}$ air gap double wall respectively.

\section{CONCLUSION}

In conclusion, the simulation result obtained showed that double skin façade incorporated to the based model office complex enhances thermal comfort in hot dry climate, Kano. Therefore, the research proposed a new model for office design which if applied could provide an office complex with efficient thermal comfort.

\section{RECOMMENDATIONS}

It is recommended that, our architects and other relevant professionals should make use of the product of this research for it will guide and help them in coming up with a better and functional office design that will to a large extent satisfy the need of workers in putting their best during working hours. It is recommended that, employers and allied professionals should recognize the significant roles of thermally comfortable environment in affecting the productivity of their employees.

\section{REFERENCES}


Adgate, J.L.; Ramachandran, G.; Pratt, G.C.; Waller, L.A.; Sexton, K. 2012, 'Spatial and temporal variability in outdoor, indoor, and personal PM2.5 exposure'. Atmos. Environ. 2002, 36, 3255-3265.Buildings 2012

AIRED 2016, 'Yonserou-Korea: Centre for Sustainable Buildings AIRED'

Alessi, B. 2008, 'Double skin facade and its benefits'. Denmark: Copenhagen Technical University. Alibaba, H. 2011, 'Thermal comfort of multiple-skin facades in warm climate offices' DOI

American Soceity for Heating, R. A. 2010, 'Thermal Environmental Conditions for Human Occupancy' Atlanta: American Society for Heating and Air Conditioning Engineers.

Ango, A. J. 2016, 'Lecture series, department of architecture' Ahmadu Bello University, Zaria.

Azarbayjani, M. 2010, 'Beyond arrows: energy performance of a new naturally ventilated double skin facade configuration for a high-rise office building in Chicago' Illinois USA: Urbana-Champaign.

Batagarawa, A. N. 2011, 'Disaggregating Primary Electricity Consumption in Office Buildings in Nigeria'. 1st Conference of International of International Building Simulation performance. Sydney.

Belgian Building Research Institute- BBRI. 2004, 'Ventilated double facades-classification and illustration of facade concepts' department of building physics, Indoor Climate and Building Services.

Berevzovska, E. 2011, 'Double Skin glass facades: Benefit for the indoor enviroment in urban areas'. Denmark: Via University College Arhus.

DailyTrust. 2017, 'Kano Partners Brains and Hammers to float Economic city'. Daily Trust Nigeria.

Deen, H. 2014, 'Passive and active environmental control'. New York: The McGraw-Hills Companies.

Eggers, I. M. 2009, 'Facade integrated hybrid ventilation system for school buildings'. Germany: RWTH Aschen University, E, On Energy research center.

Garba, A. 2015, 'An Analysis of Thermal Comfort Indices Based on the Temperature Humidity Index of Zaria, Kaduna state, Nigeria'. Unpublished Master's Thesis Ahmadu Bello University Zaria.

Gratia, E. 2004, 'Is Day Natural Ventilation Still Possible In Office Buildings With A DoubleFacade? Building and Environment.

Gruner, M. 2012, 'the potential of facade-integrated ventilation system in Nordic climate'. Norway: NTNU University.

Le Treut H, Sormerville T, Cubash U., Ding Y., Mauritzen C., Mokssit A., Peterson T., Prather M., Qin D., Manning M., Chen Z., Marquis M., Arveryt K.B., Tignor M. 2017, 'Historical Overview Climate Change'. Earth.

Lin T, Ho T., Wang Y. 2011, 'Mortality risk associated with temperature and prolonged temperature extremes in elderly populations in Taiwan Environs'. Taiwan.

Meyer-Boake, T. H. 2011, 'The Tectonics of the Environmental Skin', University of Waterloo.

M. Mohan, A. Gupta and S. Bhati 2014, 'A Modified Approach to Analyse Thermal Comfort Classification,' Atmospheric and Climate Sciences, Vol. 4 No. 1, pp. 7-19.

Oesterle, E. L. 2005, 'Double-skin facades: Integrated Planning'. Munich, London, New York: Prestel.

Poirazis, H. 2014, 'Double Skin Facade for Office Buildings- Literature Review'. Sweden: Department of Construction and Architecture, Lund University.

Saelens D, Blocken B, Roels S, Hens H. 2005, 'Optimization of the energy performance of multiple-skin facades' NINTH International IBPSA conference. Montherel, Canada.

Santamouris, N. 2007, 'Advances in passive cooling'. London: Earthscan.

Schulze, T. 2013, 'Controlled Natural ventilation for energy efficient buildings'. Energy and Building (Vol. 56). 
Wolfgang S. 2005, 'Intelligent Energy'. State of the art, 7.

Yilmaz, Z. 2007, 'Comparison of Thermal Performance of Building in Temperature-Humid and Hot Dry Climate Energy Building'. (Vol. 3). 